\title{
Weight-length relationship, condition factor and blood parameters of farmed Cichla temensis Humboldt, 1821 (Cichlidae) in central Amazon
}

\author{
Marcos Tavares-Dias ${ }^{1}$, Adriana Maria de Castro Monteiro², Elizabeth Gusmão Affonso ${ }^{3}$ \\ and Kárlia Dalla Santa Amaral ${ }^{1}$
}

Farming of native carnivore fish species has drawn attention due to their promising use in aquaculture. Among these species, tucunaré of the genus Cichla stand out, them being of high economical interest for sport fishing and Amazon's industry of ornamental fish. The present study describes the weight-length relationship (WLR), relative condition factor (Kn), red blood cell parameters, thrombocytes and leukocytes count of Cichla temensis Humboldt, 1821, farmed in central Amazon. Fish that underwent food training during fingerling culture received extruded ration containing $45 \%$ of crude protein during fattening, and had Kn with values from 0.925-1.199, which indicated good health condition during the culture. The equation obtained from the WLR was $\mathrm{W}=0.0073 \mathrm{Lt}^{3.1435}$, indicating an isometric growth, which is the desirable for fish of fish farm. Red blood cell counts, total thrombocyte and leukocyte counts, hematocrit, hemoglobin concentration, mean corpuscular volume (MCV), concentration of mean corpuscular hemoglobin (MCHC), lymphocytes, monocytes and neutrophils had intra-specific variation. A significant $(\mathrm{p}<0.001)$ positive correlation of the red blood cells number with the hemoglobin concentration and hematocrit was found. These are the first sets of blood parameters for $C$. temensis and could be used as reference for comparison in further studies to evaluate the health status of this fish in different environments, because assessment of these parameters may be used as quick tool for diagnosing diseases, stress and malnutrition.

A criação de peixes carnívoros nativos vem recebendo grande atenção devido ao promissor uso na aquicultura. Entre estes peixes destacam-se os tucunarés do gênero Cichla, de grande interesse para a pesca esportiva e a indústria de peixes ornamentais da Amazônia. O presente estudo descreve a relação peso-comprimento, fator de condição relativo (Kn) e parâmetros sanguíneos do tucunaré Cichla temensis Humboldt, 1821 cultivado na Amazônia central. Os peixes submetidos a treinamento alimentar na alevinagem receberam ração extrusada contendo $45 \%$ de proteína bruta na engorda e tiveram Kn variando de 0,925-1,199, indicando boas condições de higidez no cultivo. A equação obtida da relação peso-comprimento foi $\mathrm{P}=0,0073$.Ct $\mathrm{t}^{3,1435}$, indicando crescimento do tipo isométrico, que é o mais desejável para peixes em uma piscicultura. O número de eritrócitos, trombócitos e leucócitos totais, hematócrito, concentração de hemoglobina, volume corpuscular médio (VCM), concentração da hemoglobina corpuscular média (CHCM), linfócitos, monócitos e neutrófilos mostrou variação intra-específica. Foi observada correlação positiva significativa $(\mathrm{p}<0,001)$ do número de eritrócitos totais com a concentração de hemoglobina e o hematócrito. Estes foram os primeiros resultados sobre parâmetros sanguíneos de C. temensis e poderão ser usados como referência para comparação em estudos futuros para avaliar o estado de saúde deste peixe em diferentes ambientes, pois a medida destes parâmetros pode ser usada como ferramenta rápida para diagnóstico de doenças, estresse ou desnutrição.

Key words: Culture, Freshwater fish, Hematology, Leukocytes.

\footnotetext{
${ }^{1}$ Laboratório de Aquicultura e Pesca, Embrapa - Amapá. Rodovia Juscelino Kubitschek, Km 5, 2600 , Macapá, AP, Brazil. marcostavares@cpafap.embrapa.br

${ }^{2}$ Instituto de Saúde e Biotecnologia, Universidade Federal do Amazonas (UFAM). Estrada Coari-Mamiá, 305, Coari, AM, Brazil.

${ }^{3}$ Coordenação de Pesquisa em Aquicultura (CPAQ), Instituto Nacional de Pesquisas da Amazônia (INPA). Manaus, AM, Brazil.
} 


\section{Introduction}

Brazil has the biggest species richness of freshwater fish in the world. Some of these species have optimal characteristics for farming; however, most of the domestic production is represented by exotic species as carp and tilapia, due to the good knowledge on farming technology of these species (Poli et al., 2004). Nowadays, cultivation of native carnivorous fish has received great attention due to the high market value that these species attain. Among Amazonian ichthyofauna, the genus Cichla comprises 15 species (Kullander \& Ferreira, 2006). These species are regarded as fish of great flavor and meat quality (absence of intramuscular spines), so they belong to one of the most commoditized species in the Amazonian region, their original drainage basin (Saint-Paul, 1986; Kullander \& Ferreira, 2006).

The tucunaré C. temensis is a species of great importance for sport fishing and commerce of ornamental fish. It reproduces naturally in vivaria, displaying spawning and parental care, something that ensures higher rates of survival for fingerlings. However, due to cannibalism during fingerling culture, maintenance of low stocking densities must also be employed to optimize survival rates (Poli et al., 2004). Such fish are carnivorous, thus needing to undergo food training to accept artificial rations. Other huge obstacle for sustaining intensive farming is ailments, which have greatly increased during the last decades (Schalch et al., 2005; Tavares-Dias et al., 2009). In addition, another barrier has been the lack of knowledge on the biology, especially concerning physiology of native species which are promising for aquaculture.

Weight-length relationship is used for estimating the weight corresponding to a given length (Gomiero \& Braga, 2003; Froese, 2006; Gomiero et al., 2008) and may be also used to determine possible differences between separate unit stocks of the same species. The condition factor is used for comparing the body condition, gonadal development, fatness, or welfare of fish, based on the assumption that heavier fish of a given length are in better condition (Gomiero \& Braga, 2003; Froese, 2006). Due to its importance, the knowledge of these quantitative indicators of health has been used in fishing biology studies since the beginning of the $20^{\text {th }}$ century (Froese, 2006).

The relative condition factor $(\mathrm{Kn})$ provides information on the variation of fish physiological status, and may be used for comparing populations living in certain feeding, climate, and other conditions (Le-Cren, 1951; Lizama \& Ambrósio, 2002; Gomiero et al., 2008). Therefore, condition factor can be used to determine the period of gonadal maturation and following up the degree of feeding activity of a species to determine whether it is making good use of its feeding source (Weatherley, 1972; Lizama \& Ambrósio, 2002; Gomiero et al., 2008). In addition, other physiological parameters can be used for evaluating the health status of the fish.

The analysis of blood parameters may be used as a relevant tool in detecting diseases (diagnosis and prognosis) that afflict fish (Tavares-Dias \& Moraes, 2004; Kori-Siakpere et al., 2005; Ranzani-Paiva et al., 2005; Tavares-Dias et al.,
2009), as well as indirectly assisting in monitoring aquatic ecosystems (Serpunin \& Likhatchyova, 1998; Kori-Siakpere et al., 2005). Thus, observations of physiopathological alterations in fish undergoing various conditions of stress have been made possible by studies related to enzymatic levels, stress indicating hormones (corticosteroids) and some blood parameters (Gabriel et al., 2004; Ranzani-Paiva et al., 2005; Tavares-Dias et al., 2009).

Piscine red blood cell parameters (red blood cell counts, hemoglobin and hematocrit) have been employed to estimate the oxygen carrying capacity, as well as to diagnose anemia and indicate systemic responses to external stimuli (TavaresDias \& Moraes, 2007; Tavares-Dias et al., 2009). White blood cell counts may indicate infections and other states of homeostatic imbalance (Serpunin \& Likhatchyova, 1998, Tavares-Dias et al., 2009). However, those parameters are directly related to genetic, physiological, and environmental factors (both biotic and abiotic) for each species, such as sex, age, and food availability in the environment (Gabriel et al., 2004; Tavares-Dias \& Moraes, 2004), which can difficult the interpretation of collected data. In addition, one of the hindrances in assessing the health of fish is the scarcity of reference values for blood parameters, the data on tropical species being negligible if compared to the richness and diversity of fish species in such ecosystems (Kori-Siakpere et al., 2005). Thus, the present study aims to provide information regarding the weight-length relationship, relative condition factor $(\mathrm{Kn})$ and blood parameters of C. temensis farmed in central Amazon.

\section{Material and Methods}

\section{Fish and conditions of cultivation}

The experiments of this study were conducted in the facilities of the Coordenação de Pesquisa em Aquacultura (CPAQ) of the Instituto de Pesquisa da Amazônia (INPA). Voucher specimen catalogued as INPA 9900. Fingerlings of Cichla temensis ( $3.5 \pm 0.3 \mathrm{~cm}$ and $2.5 \pm 0.4 \mathrm{~g}$ ) were kept in tanks measuring $120 \mathrm{~m}^{2}$, in a density of one specimen per square meter, and having underwent food training in cages. During and after fingerling culture, fish were fed with homogeneous mixture of zooplankton, minced fish meat, mineral and vitamin premix, and extruded commercial ration with $45 \%$ crude protein.

\section{Blood parameters analysis}

When the tucunare $C$. temensis reached the age of about one year, 40 specimens were collected and anesthetized with benzocaine $(0.5 \mathrm{~g} / \mathrm{L}$ of water $)$ to collect blood from the caudal vessel, using syringes containing EDTA (10\%). These procedures took 0.8-1.2 $\mathrm{min}$, to minimize stress for the fish. Blood analysis followed collection, when we determined red blood cell counts (RBC) in a Neubauer chamber, hematocrit (Hct) by the microhematocrit method, and concentration of hemoglobin $(\mathrm{Hb})$ by the oxihemoglobin method. Hematimetric indices such as mean corpuscular volume (MCV) and concentration of mean corpuscular hemoglobin (MCHC) were 
determined from values of red blood cells, hemoglobin and hematocrit (Tavares-Dias \& Moraes, 2006).

Blood smears were made and stained with the combination May Grunwald-Giemsa-Wright (Tavares-Dias \& Moraes, 2003) for differential leukocyte count, reaching 200 cells of interest. Those smears were used for the determination of the total leukocytes and thrombocytes, following recommendations from Tavares-Dias \& Moraes (2006).

\section{Weight-length relationship and relative condition factor}

For each specimen the weight $(\mathrm{g})$ was determined using a scale with precision $0.01 \mathrm{~g}$, while total body length $(\mathrm{cm})$, with an ichthyometer. These data were used to find the relative condition factor (Le Cren, 1951) and the weight-length relationship (WLR), making use of Equation 1:

$$
\mathrm{W}=\mathrm{a} \cdot \mathrm{L} \mathfrak{t}^{\mathrm{b}}(1)
$$

Where $\mathrm{W}$ stands for total weight in grams, $\mathrm{Lt}$ for total length in centimeters and $\mathbf{a}$ and $\mathbf{b}$ are constants. Both these constants were estimated by a linear regression of Equation 2 transformed:

$$
\mathrm{W}=\log \mathrm{a}+\mathrm{b} \times \log \mathrm{L}(2)
$$

\section{Statistical analyses}

In study of the WLR, the level of significance of $\mathbf{r}$ was estimated and the value of $\mathbf{b}$ was tested using the Student's t-test $(p<0.05)$, to know if $\mathbf{b}=3.0$. The relative condition factor $(\mathrm{Kn})$ was tested with the standard $\mathrm{Kn}=1.00$, by Student's t-test $(\mathrm{p}<0.05)$.

\section{Water quality analyses}

To analyze variations in physiochemical parameters of water quality during the experiment, we performed weekly analysis of dissolved oxygen (DO), hydrogen potential $(\mathrm{pH})$, temperature and electrical conductivity and total ammonia. Values of DO varied from 5.5 to $6.5 \mathrm{mg} / \mathrm{L}$, temperature from $27.8-29.0^{\circ} \mathrm{C}, \mathrm{pH}$ from $5.5-6.0$, electrical conductivity from 24.0 $32.0 \mu \mathrm{s}^{\mathrm{cm}-1}$ and total ammonia from $0.8-1.0 \mathrm{mg} / \mathrm{L}$.

\section{Results}

Values of weight, total length, relative condition factor $(\mathrm{Kn})$ and blood parameters of $C$. temensis can be seen in Table 1 . The weight-length relationship among pairs of plotted data, values of determination coefficients $\left(\mathrm{R}^{2}\right)$ and corresponding equation are demonstrated in Fig. 1.

Table 1. Mean values \pm Standard deviation (SD), and minimum and maximum for biometric and blood parameters of C. temensis $(\mathrm{n}=40)$ farmed in central Amazon.

\begin{tabular}{lcc}
\hline Parameters & Mean $\pm \mathrm{SD}$ & Minimum-Maximum \\
\hline Weight $(\mathrm{g})$ & $130.8 \pm 44.2$ & $40.0-220.0$ \\
Length $(\mathrm{cm})$ & $22.2 \pm 2.5$ & $16.5-27.0$ \\
Kn & $1.00 \pm 0.04$ & $0.925-1.199$ \\
$\mathrm{RBC}\left(\mathrm{x} 10^{6} / \mu \mathrm{L}\right)$ & $1.420 \pm 0.121$ & $0.970-1.600$ \\
$\mathrm{Hb}(\mathrm{g} / \mathrm{dL})$ & $6.3 \pm 0.6$ & $4.3-7.4$ \\
$\mathrm{Hct}(\%)$ & $23.9 \pm 2.1$ & $16.0-27.0$ \\
$\mathrm{MCV}(\mathrm{fL})$ & $168.3 \pm 4.6$ & $154.4-178.1$ \\
MCHC $(\mathrm{g} / \mathrm{dL})$ & $26.4 \pm 1.2$ & $23.6-29.7$
\end{tabular}

The equation that describes this relationship is $\mathrm{W}=$ $0.0073 \mathrm{Lt}^{3.1435}$, given that the obtained value for the slope (b) of the weight-length relationship shows that relative growth is allometric. $\mathrm{Kn}(0.925$ to 1.199$)$ was not different from 1.00, according to the $t$-test.

In C. temensis, the number of red blood cells, hematocrit, hemoglobin, MCV and MCHC varied (Table 1). There was a highly significant $(\mathrm{p}<0.001)$ positive correlation of red blood cells number with the concentration of hemoglobin $[\mathrm{Hb}=-$ $0.246+(4.605 \times \mathrm{RBC})]$ (Fig. 2) and hematocrit $[\mathrm{RBC}=0.144+$ $(0.0534 \mathrm{x} \mathrm{Hct})]$ (Fig. 3). Positive correlation was also observed between hematocrit and concentration of hemoglobin $[\mathrm{Hb}=$ $0.623+(0.237 \times$ Hct $)]$ (Fig. 4).

Values on total thrombocyte and leukocyte counts are shown in Table 2. In C. temensis, red blood cells, thrombocytes and leukocytes (lymphocytes, monocytes and neutrophils) were found in blood smears stained with May Grunwald-Giemsa-Wright (MGGW). Mature red blood cells usually have with elliptical shape, acidophilic cytoplasm and nucleus following the general shape of the cell (Fig. 5A).

Polychromatic erythroblasts are cells larger than mature red blood cells, with varying size and cytoplasmic staining (Fig. 5B). Neutrophils are predominantly rounded, their cytoplasm containing neutrophilic fine granulations. Their nucleus is rodshaped, occasionally segmented and, generally, eccentric, its nuclear chromatin being mildly compact, lacking a visible
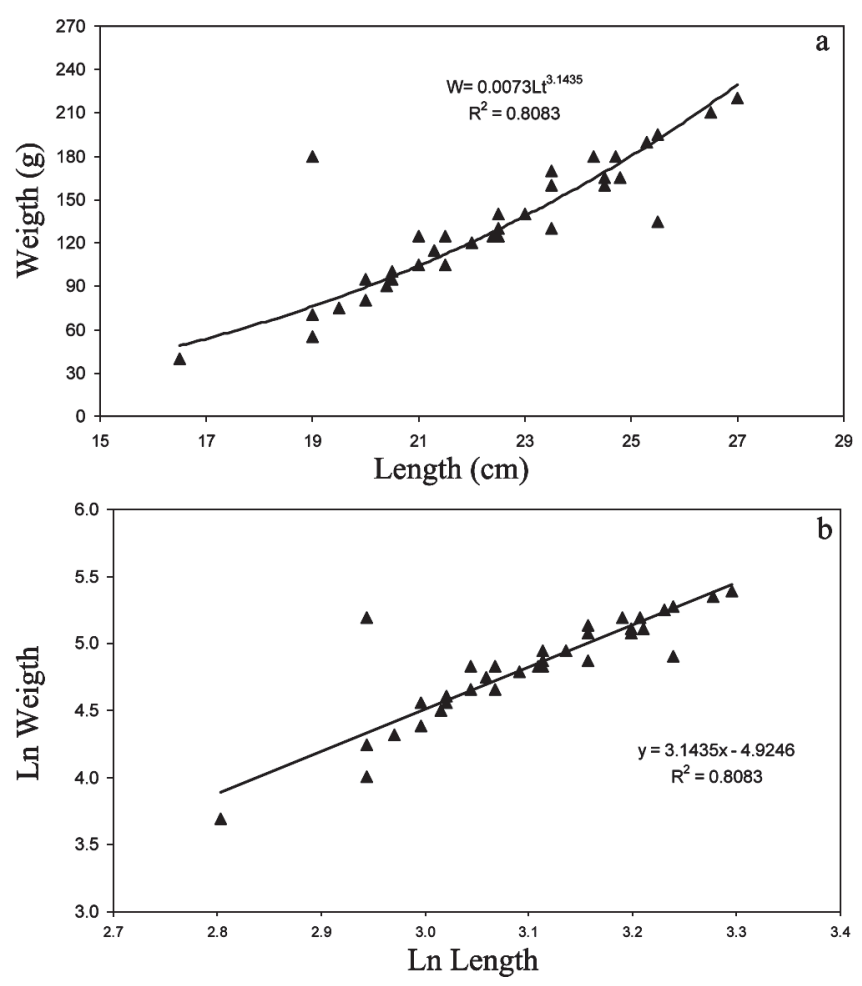

Fig. 1. Weight-length relationship in Cichla temensis $(\mathrm{n}=40)$ farmed in central Amazon. Data values as plotted: a. Values of the determination coefficient/R2; $\mathbf{b}$. Linear regression. 


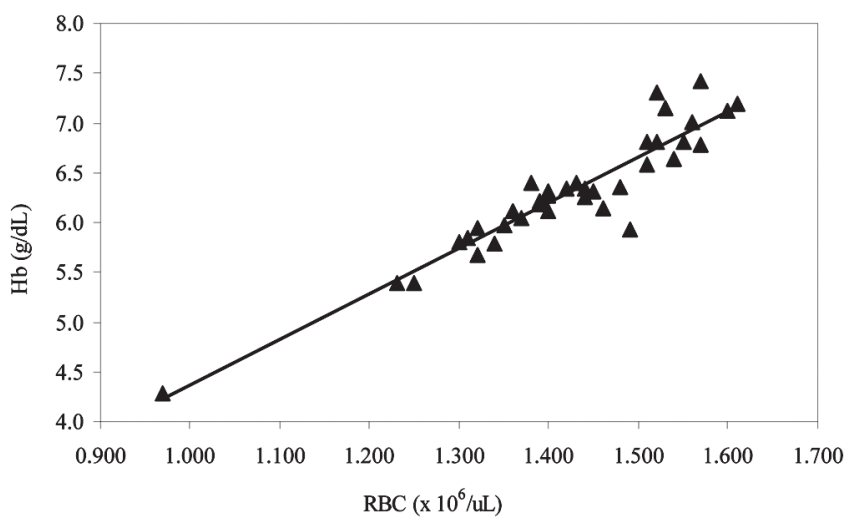

Fig. 2. Relationship between red blood cells $(r=0.938 ; \mathrm{p}<0.001)$ and hemoglobin concentration in C. temensis $(\mathrm{n}=40)$ farmed in central Amazon.

nucleolus (Fig. 5C). Monocytes are generally rounded cells, larger than lymphocytes, with a basophilic cytoplasm that may have vacuoles or not. Nucleus is usually beveled and occasionally rounded (Fig. 5D). Lymphocytes are predominantly rounded cells with varying size and basophilic cytoplasm, without visible granules, and often displaying cytoplasmic projections. Their nucleus is rounded and has dense chromatin, which shows high relationship with the cytoplasm (Fig. 5E). Thrombocytes are usually rounded cells, their cytoplasm sporting a hyaline staining and following the shape of the cell (Fig. 5F).

\section{Discussion}

Several fish species with carnivorous habits are adapted to captivity, such as golden dorado Salminus brasiliensis (Cuvier, 1816) and S. affinis (Steindachner, 1880) channel catfish Ictalurus punctatus (Rafinesque, 1818), rainbow trout Oncorhynchus mykiss (Walbaum, 1792), barred sorubim Pseudoplatystoma spp., and Arapaima gigas (Schinz, 1822). However, the culture system (intensive, semi-intensive or extensive) notwithstanding, productivity is directly related to water quality, mainly the dissolved oxygen levels (Boyd, 2001). While fish of the genus Cichla inhabit lentic waters,

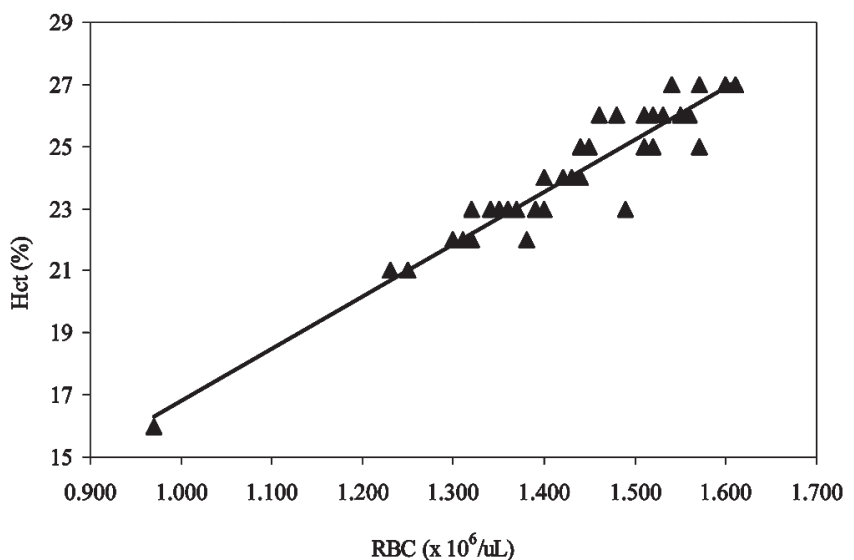

Fig. 3. Relationship between hematocrit and red blood cells $(r=0.950$; $\mathrm{p}<0.001)$ in C.temensis $(\mathrm{n}=40)$ farmed in central Amazon.

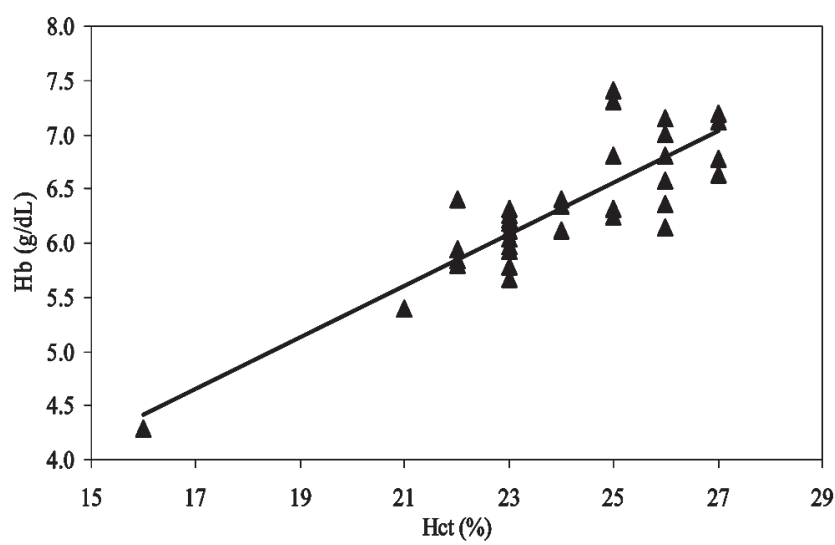

Fig. 4. Relationship between hematocrit and hemoglobin concentration $(r=0.860 ; \mathrm{p}<0.001)$ in C. temensis $(\mathrm{n}=40)$ farmed in central Amazon.

these fish are extremely demanding of dissolved oxygen levels, and they also display sensibility to low temperatures. In this study, parameters of water quality were within optimal values for the cultivation of $C$. temensis, a tropical species.

In the farming environment there is greater control over biotic and some of the abiotic factors, but, regardless of that, the allometric weight-length relationship for $C$. temensis was the same as the one described for other species of the genus Cichla, such as Cichla ocellaris, Cichla monoculus Bloch \& Schneider, 1801 (Gomiero \& Braga, 2003), Cichla orinosensis, Cichla temensis Humboldt, 1821 (Jepsen et al., 1999; Winemiller, 2001) and Cichla intermedia Machado Allison, 1971 (Jepsen et al., 1999), which live in the wild. On other species of cichlids, such as Astronotus crassipinnis (Heckel, 1840) and Geophagus proximus (Castelnau, 1855), growth was also allometric (Ruffino \& Isaac, 1995). However, for C. kelberi with grouped sexes the weight-length relationship was $\mathrm{W}=$ 0.000009209 $\mathrm{Lt}^{3.093}$ (Gomiero et al., 2008). As in wild environments predation and competition (both intra and interspecific) take place, the expected weight-length relationship should be lower than that found for farmed fish. Nevertheless, when farmed species are under stressful conditions, be them caused by inadequate handling or illness, the weight-length relationship can also considerably decrease.

Although the relative condition factor for $C$. ocellaris and $C$. monoculus has varied during the studied period (Gomiero \& Braga, 2003), mean values $(\mathrm{Kn}=1.00)$ were similar

Table 2. Mean values \pm Standard deviation (SD), and minimum and maximum for total thrombocyte and leukocyte counts of C. temensis $(\mathrm{n}=40)$ farmed in central Amazon.

\begin{tabular}{lcc}
\hline Parameters & Mean \pm SD & Minimum-Maximum \\
\hline Thrombocytes $(\mu \mathrm{L})$ & $28,619 \pm 13,148$ & $11,120-78,100$ \\
Leukocytes $(\mu \mathrm{L})$ & $13,163 \pm 6857$ & $3080-31,710$ \\
Lymphocytes $(\mu \mathrm{L})$ & $9308 \pm 5864$ & $3218-21,638$ \\
Lymphocytes $(\%)$ & $68.6 \pm 20.8$ & $24.0-87.0$ \\
Monocytes $(\mu \mathrm{L})$ & $1433 \pm 842$ & $493-3120$ \\
Monocytes $(\%)$ & $11.3 \pm 4.5$ & $5.0-19.0$ \\
Neutrophils $(\mu \mathrm{L})$ & $2314 \pm 1766$ & $402-5292$ \\
Neutrophils $(\%)$ & $20.1 \pm 18.8$ & $5.0-63.0$
\end{tabular}



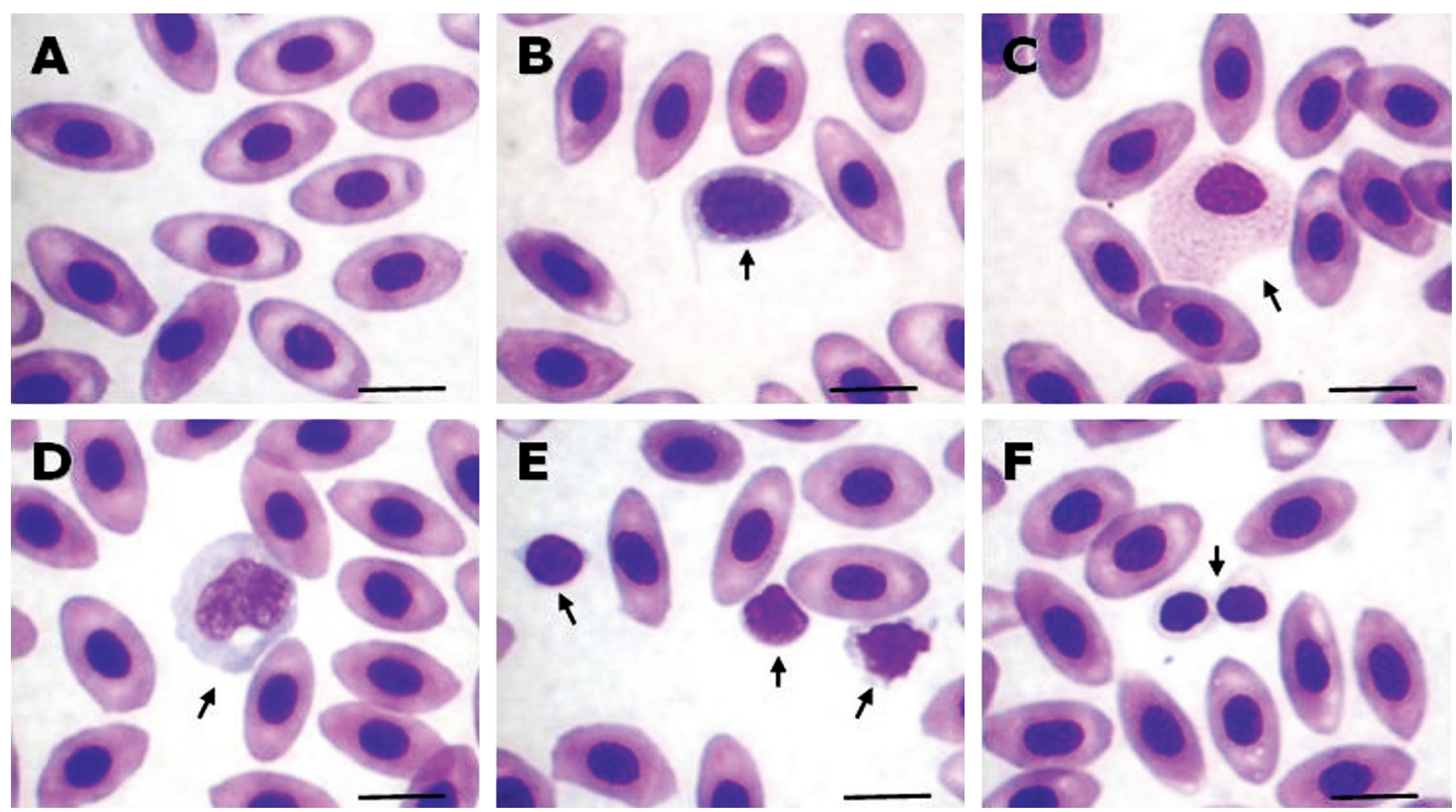

Fig. 5. Blood cells in tucunaré C. temensis stained by MGGW. A - Erythrocytes, B - Polychromatic erythroblasts, C - Neutrophil, $\mathbf{D}$ - Monocyte, $\mathbf{E}$ - Lymphocyte, and $\mathbf{F}$ - Thrombocytes. Scale bars $=5 \mu \mathrm{m}$.

to those for C. temensis in the present study. However, for farmed I. punctatus Kn was higher than 1.00 (Tavares-Dias \& Moraes, 2007). Therefore, this indicates good body condition of $C$. temensis in culture, making good use of the artificial feeding source in the fish farming.

Blood is the most accessible component of the fish body fluid system. Accordingly, it is the tissue most frequently examined in attempts to assess physiological status. On red blood cell parameters, we observed that $C$. temensis, when compared to other freshwater carnivorous species, displayed lower red blood cells count, MCV and MCHC. On the other hand, in C. temensis the mean values of hemoglobin were higher than those recorded for Pseudoplatystoma fasciatum (Linnaeus, 1766) and Hoplias malabaricus (Bloch, 1794), as well as hematocrit in North African catfish Clarias gariepinus (Burchell, 1822) and spotted sorubim Pseudoplatystoma corruscans (Spix \& Agassiz, 1829) (Table 3). Furthermore, a positive correlation between red blood cell counts, hematocrit and hemoglobin was observed in this study, indicating no discrepant influences when determining these red blood cell parameters. Similar correlations were described for A. gigas (Araújo et al., 2009) and the hybrid surubim P. reticulatum $\mathrm{x}$ P. corruscans (Tavares-Dias et al., 2009), species that are both carnivorous and kept under intensive cultivation. Such higher hemoglobin content in C. temensis reflects greater metabolic activity (Tavares-Dias \& Moraes, 2004; TavaresDias et al., 2008), and presumably would reflect also better physiological adaptation to survive in environments with seasonal fluctuations of oxygen levels, which occur in the Amazonian basin. Therefore, red blood cell parameters are useful measures of respiratory adaptation that could be used for fish living in different environments.

Table 3. Mean values of red blood cell parameters for different species of carnivorous fish from literature. $\mathrm{RBC}=$ Red blood cell counts; $\mathrm{Hb}=$ hemoglobin; $\mathrm{Hct}=$ hematocrit; $\mathrm{MCV}=$ Mean corpuscular volume; $\mathrm{MCHC}=$ Mean corpuscular hemoglobin. $-=$ No information.

\begin{tabular}{|c|c|c|c|c|c|c|}
\hline Species/Environment & $\mathrm{RBC}\left(\times 10^{6} / \mu \mathrm{l}\right)$ & $\mathrm{Hb}(\mathrm{g} / \mathrm{dL})$ & Hct $(\%)$ & MCV (fL) & $\mathrm{MCHC}(\mathrm{g} / \mathrm{dL})$ & \\
\hline Ictalurus punctatus/farmed & 3.000 & 7.0 & 31.0 & 108.1 & 22.0 & Tavares-Dias \& Moraes (2007) \\
\hline Clarias gariepinus/wild & 2.500 & 7.9 & 23.0 & 93.3 & 36.1 & Gabriel et al. (2004) \\
\hline Clarias isheriensis/wild & 1.550 & 14.5 & 31.6 & 207.3 & 46.4 & Kori-Siakpere (1984) \\
\hline Pseudoplatystoma fasciatum/farmed & 1.697 & 5.2 & 25.0 & 151.7 & 20.9 & Ranzani-Paiva et al. (2005) \\
\hline Pseudoplatystoma corruscans/farmed & - & - & 23.4 & - & - & Beelen et al. (1998) \\
\hline Salminus affinis/wild & 2.200 & 12.5 & 36.2 & 163.8 & 35.0 & Atencio-Gárcia et al. (2007) \\
\hline Salminus maxillosus/wild & 2.149 & 8.9 & 43.6 & 207.0 & 20.8 & Ranzani-Paiva et al. (2001) \\
\hline Hoplias malabaricus/wild & 2.050 & 4.8 & 26.5 & 139.8 & 27.9 & Rios et al. (2005) \\
\hline Arapaima gigas/farmed & 4.123 & 10.4 & 34.4 & 83.3 & 30.2 & Tavares-Dias et al. (2007) \\
\hline Cichla temensis/farmed & 1.420 & 6.3 & 23.9 & 168.30 & 26.40 & Present study \\
\hline
\end{tabular}


Table 4. Mean values of thrombocyte and leukocyte counts for species of carnivorous fish from literature. - = No information.

\begin{tabular}{|c|c|c|c|c|c|c|c|}
\hline Parameters/Species & $\begin{array}{c}\text { Clarias } \\
\text { gariepinus }\end{array}$ & $\begin{array}{c}\text { Salminus } \\
\text { brasiliensis }\end{array}$ & $\begin{array}{l}\text { Salminus } \\
\text { affinis }\end{array}$ & $\begin{array}{l}\text { Arapaima } \\
\text { gigas }\end{array}$ & $\begin{array}{l}\text { Ictalurus } \\
\text { punctatus }\end{array}$ & $\begin{array}{c}\text { Hoplias } \\
\text { malabaricus }\end{array}$ & $\begin{array}{c}\text { Cichla } \\
\text { temensis }\end{array}$ \\
\hline & $\begin{array}{l}\text { Gabriel et al. } \\
\text { (2004) }\end{array}$ & $\begin{array}{c}\text { Ranzani-Paiva et al. } \\
(2003)\end{array}$ & $\begin{array}{c}\text { Atencio-Gárcia et } \\
\text { al. (2007) }\end{array}$ & $\begin{array}{c}\text { Tavares-Dias et al. } \\
(2007)\end{array}$ & $\begin{array}{l}\text { Tavares-Dias \& } \\
\text { Moraes (2007) }\end{array}$ & $\begin{array}{l}\text { Rios et al. } \\
(2005)\end{array}$ & $\begin{array}{c}\text { Present } \\
\text { study }\end{array}$ \\
\hline Thrombocyte $(\mu \mathrm{L})$ & - & - & 25.400 & 46.097 & 77.870 & 14.600 & 28.619 \\
\hline Leukocytes $(\mu \mathrm{L})$ & - & - & 6100 & 15.833 & 35.788 & 54.700 & 13.163 \\
\hline Lymphocytes $(\mu \mathrm{L})$ & - & - & - & 12.669 & 9112 & 53.600 & 9308 \\
\hline Lymphocytes (\%) & 48.8 & 53.1 & 68.8 & 80.2 & - & 86.5 & 68.6 \\
\hline Monocytes $(\mu \mathrm{L})$ & - & - & - & 748 & 5253 & 4400 & 1433 \\
\hline Monocytes (\%) & 3.6 & 5.8 & 2.1 & 5.3 & - & 7.08 & 11.3 \\
\hline Neutrophils $(\mu \mathrm{L})$ & - & - & - & 2419 & 19.038 & 1900 & 2314 \\
\hline Neutrophils (\%) & 49.1 & 33.3 & 28.4 & 14.3 & - & 3.2 & 20.1 \\
\hline
\end{tabular}

Piscine blood leukocytes are the major cell components involved in immune response (Tavares-Dias \& Moraes, 2007; Tavares-Dias et al., 2008). In general, among the leukocytes found are lymphocytes, neutrophils, monocytes, eosinophils, basophils and PAS-positive granular leukocytes (Tavares-Dias \& Moraes, 2004), depending on species. However, C. temensis has only lymphocytes, monocytes and neutrophils, which were the only leukocytes also reported for S. affinis (Table 4). Hence, this indicates similar functioning of the immune system for both species. On the other hand, $C$. temensis has all blood leukocytes known for fish, while A. gigas and S. maxillosus have no basophils, and I. puctatus has no eosinophils (Table 4). Environmental pressure during evolution seems to have induced adaptations in the tissue distribution of the cells involved in the immune system of fish, therefore the granulocytes may have evolved similarly (Tavares-Dias et al., 2008). Since neutrophils were the only granulocytes found in C. temensis blood, we could assume that, during this evolution of the immune system, they became the most important granulocytes for the immune defense of this neotropical fish.

On thrombocyte and leukocyte counts, we observed that $C$. temensis displays the lowest number of total thrombocytes and leukocytes when compared to other species of carnivorous fish in specialized literature, as can be seen in Table 4. In C. temensis, about $80 \%$ of the leukocytes were lymphocytes and monocytes. However, lymphocyte counts were similar to that seen in S. affinis, while monocyte and neutrophil counts differed. These differences were species-specific, in addition different methodologies employed for counting total leukocytes and thrombocytes might affect these results from literature (TavaresDias \& Moraes, 2006; Tavares-Dias et al., 2009).

In conclusion, since the species here compared have some similar features, such as feeding habits, environmental preference and good health status, other factors, such as respiratory physiology and thermal preferences, were also responsible for the intra-specific differences in hematological parameters. Furthermore, differences in blood sampling and environmental characteristics of habitat, be it either a natural or farming environment, may also influence some blood parameters, causing differences highlighted in this study. Therefore, the fish blood parameters are important bioindicators of their physiological status and a helpful tool in the evaluation of their immune system, but only when they are correctly interpreted.

\section{Acknowledgements}

The authors would like to thank the CNPq for the grant (Proc. \# 300472/2008-0/PQ) to M. Tavares-Dias and grant for Technical Support (Proc. \#501672/2008-7).

\section{Literature Cited}

Araújo, C. S. O., M. C. Barros, A. L. S. Gomes, A. M. B. Varella, G. M. Viana, N. P. Silva, E. C. Fraga \& S. M. S. Andrade. 2009. Parasitas de populações naturais e artificiais de tucunaré (Ciclha spp.). Revista Brasileira de Parasitologia Veterinária, 18: 34-38.

Atencio-Garcia, V., F. G. Lopez, D. M. Mendoza \& S. P. Carrasco. 2007. Hematología y química sanguínea de juveniles de rubio Salminus affinis (Pisces: Characidae) del Río Sinú. Acta Biologica Colombiana, 12: 27-40.

Beelen, R., T. Van der Heijden, M. Verdegem \& G. C. Pavanelli. 1998. Blood values of young Brazilian catfish Pseudoplatystoma corruscans (Agassiz, 1829). Acta Scientiarum, 20: 147-150.

Boyd, C. E. 2001. Manejo da qualidade da água na aquicultura e no cultivo do camarão marinho. Recife, PE. Associação Brasileira de Criadores de Camarão, ABCC, 157p.

Froese, R. 2006. Cube law, condition factor and weight-length relationships: history, meta-analysis and recommendations. Journal of Applied Ichthyology, 22: 241-253.

Gabriel, U. U., G. N. O. Ezeri \& O. O. Opabunmi. 2004. Influence of sex, source, health status and acclimation on the haematology of Clarias gariepinus (Burch, 1822). African Journal of Biotechnology, 3: 463-467.

Gomiero, L. M. \& F. M. S. Braga. 2003. Relação peso-comprimento e fator de condição para Cichla $\mathrm{cf}$. ocellaris e Cichla monoculus (Perciformes, Cichlidae) no reservatório de Volta Grande, rio Grande - MG/SP. Acta Scientiarum Biological Sciences, 25: 79-86.

Gomiero, L. M., G. A. Villares Junior \& F. Naous. 2008. Relação pesocomprimento e fator de condição de Cichla kelberi (Perciformes, Cichlidae) introduzidos em um lago artificial no Sudeste brasileiro. Acta Scientiarum Biological Sciences, 30: 173-178.

Jepsen, D. B., K. O. Winemiller, D. C. Taphorn \& D. R. Olarte. 1999. Age structure and growth of peacock cichlids from rivers and reservoirs of Venezuela. Journal of Fish Biology, 55: 433-50.

Kori-Siakpere, O., J. E. G. Ake \& E. Idoge. 2005. Haematological characteristics of the African snakehead Parachanna obscura. African Journal of Biotechnology, 4: 527-530.

Kullander, S. O \& E. J. G. Ferreira. 2006. A review of the South American cichlid genus Cichla, with descriptions of nine new species (Teleostei: Cichlidae). Ichthyological Exploration of Freshwaters, 17: 289-398 
Le-Cren, E. D. 1951. The length-weight relationship and seasonal cycle in gonadal weight and condition in the perch (Perca fluviatilis). Journal of Animal Ecology, 20: 201-219.

Lizama, M. A. P. \& A. M. Ambrósia. 2002. Condition factor in nine species of fish of the Characidae family in the upper Paraná River floodplain, Brazilian Journal of Biology, 62: 113-124.

Poli, C. R., A. T. B. Poli, E. Andreatta \& E. Beltrame. 2004. Aquicultura: experiências Brasileiras. Universidade Federal de Santa Catarina Departamento de Aquicultura, Florianópolis, 456p.

Ranzani-Paiva, M. J. T., E. L. Rodrigues, M. L. Veiga \& A. C. Eiras. 2001. Association between the hematological characteristics and the biology of the "dourado" Salminus maxillosus Valenciennes, 1840 from Mogi-Guaçu River, state of São Paulo, Brazil. Acta Scientiarum Biological Sciences, 23: 527-533.

Ranzani-Paiva, M. J. T., E. L. Rodrigues, M. L. Veiga, A. C. Eiras \& B. E. S. Campos. 2003. Differential leukocyte counts in "dourado" Salminus maxillosus Valenciennes, 1840 from the MogiGuaçu River, Pirassununga, SP. Brazilian Journal of Biology, 63: 517-525.

Ranzani-Paiva, M. J. T., E. Romagosa \& C. M. Ishikawa. 2005. Hematological parameters of "cachara" Pseudoplatystoma fasciatum Linnaeus, 1766 (Osteichthyes, Pimelodidae), reared in captivity. Boletim do Instituto de Pesca, 31: 47-53.

Rios, F. S., E. T. Oba, M. N. Fernandes, A. L. Kalinin \& F. T. Rantin. 2005. Erythrocyte senescence and haematological changes induced by starvation in the neotropical fish traíra, Hoplias malabaricus (Characiformes, Erythrinidae). Comparative Biochemistry Phisiology, 140A: 281-287.

Ruffino, M. L. \& V. J. Isaac. 1995. Life cycle and biological parameters of several Brazilian Amazon fish species. ICLARM Quartely, 18: 41-45.

Saint-Paul, U. 1986. Potential of aquaculture for South American fresh water fishes: a review. Aquaculture, 54: 205-240.

Schalch, S. H. C., M. A. A. Belo, V. E. Soares, J. R. E. Moraes \& F. R. Moraes. 2005. Eficácia do diflubenzuron no controle de Dolops carvalhoi (Crustacea: Branchiura) em jovens pacus Piaractus mesopotamicus (Osteichthyes: Characidae) naturalmente infectados. Acta Scientiarum Biological Sciences, 27: $297-$ 302.
Serpunin, G. G. \& O. A. Likhatchyova. 1998. Use of the ichthyohaematological studies in ecological monitoring of the reservoirs. Acta Veterinaria, 67: 339-345.

Tavares-Dias, M. \& F. R. Moraes. 2003. Características hematológicas da Tilapia rendalli Boulenger, 1896 (Osteichthyes: Cichlidae) capturada em "pesque-pague" de Franca, São Paulo, Brasil. Bioscience Journal, 19: 103-110.

Tavares-Dias, M \& F. R. Moraes. 2004. Hematologia de peixes teleósteos. Riberão Preto, Villimpress, 144p.

Tavares-Dias, M. \& F. R. Moraes. 2006. Hematological parameters for the Brycon orbignyanus Valenciennes, 1850 (Osteichthyes, Characidae) intensively bred. Hidrobiológica, 16: 271-274.

Tavares-Dias, M. \& F. R. Moraes. 2007. Leukocyte and thrombocyte reference values for channel catfish (Ictalurus punctatus Raf.), with an assessment of morphological, cytochemical, and ultrastructural features. Veterinary Clinical Pathology, 36: 4954.

Tavares-Dias, M., J. F. M. Barcellos, J. L. Marcon, J. C. Menezes, E. A. Ono \& E. G. Affonso. 2007. Hematological and biochemical parameters for the pirarucu Arapaima gigas Schnz, 1822 (Osteoglossiformes, Arapaimatidae) in the cage culture. Electronic Journal of Ichthyology, 2: 61-68.

Tavares-Dias, M., F. R. Moraes, M. E. Imoto. 2008. Hematological parameters in two neotropical freshwater teleost, Leporinus macrocephalus (Anostomidae) and Prochilodus lineatus (Prochilodontidae). Bioscience Journal, 24: 96-101.

Tavares-Dias, M., M. M. Ishikawa, M. L. Martins, F. Satake, H. Hisano, S. B. Pádua, G. T. Jerônimo \& A. R. Sant Ana. 2009. Hematologia: ferramenta para o monitoramento do estado de saúde de peixes em cultivo. Pp. 43-80. In: Saran-Neto, A., W. S. Mariano \& S. F. Pozzobon-Soria (Org.). Tópicos especiais em saúde e criação animal. 1 Ed. São Carlos, Pedro \& João Editores.

Weatherlley, A. H.1972. Growth and ecology of fish population. London, Academic Press.

Winemiller, K. O. 2001. Ecology of peacock cichlids (Cichla spp.) in Venezuela. Journal of Aquatic Sciences, 9: 93-112.

Accepted October 26, 2010

Published March 31, 2011 